\title{
A Novel Telescoped Kilogram-Scale Process for Preparation of Obeticholic Acid
}

\author{
Cheng-Wei Li $\mathrm{Li}^{1,2}$ Cai Wang ${ }^{2}$ Chao Guo ${ }^{2}$ Bin-Hua Lv* You-Fu Luo $^{1 *}$
}

\author{
${ }^{1}$ State Key Laboratory of Biotherapy and Cancer Center, West China \\ Hospital, West China Medical School, Sichuan University, Chengdu, \\ People's Republic of China \\ ${ }^{2}$ Suzhou Zelgen Biopharmaceuticals Co., Ltd., Kunshan, People's \\ Republic of China
}

Pharmaceut Fronts 2021;3:e56-e64.
Address for correspondence Bin-Hua Lv, PhD, Suzhou Zelgen Biopharmaceuticals Co., Ltd., 209 Chenfeng Road, Kunshan 215300, People's Republic of China (e-mail: Ivbh@zelgen.com).

You-Fu Luo, PhD, State Key Laboratory of Biotherapy and Cancer Center, West China Hospital, West China Medical School, Sichuan University, Gaopeng Street, Keyuan Street Road 4, Chengdu 610041, People’s Republic of China (e-mail: luo_youfu@scu.edu.cn).

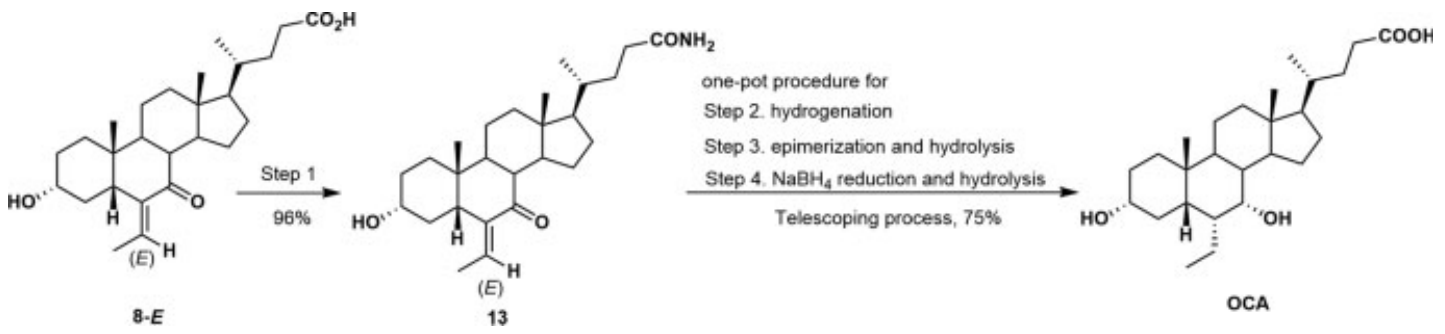
Abstract
Keywords
- obeticholic acid
- four-step process
- amide intermediate
- kilogram-scale production

A novel scalable four-step process has been developed to improve the synthesis of obeticholic acid (OCA). The key step of this process was the isolation of the amide intermediate, which underwent hydrogenation, basic epimerization, ketone reduction, and amide hydrolysis in a one-pot procedure. The use of efficient single recrystallization for the final purification in this process made the corresponding work-up procedure more concise and environmentally friendly. A kilogram-scale production of OCA following this process could achieve over $70 \%$ yield with all impurities controlled below $0.10 \%$.

\section{Introduction}

Obeticholic acid (OCA, or 7-ECDCA) is a selective agonist of farnesoid X receptor (FXR) with the $6 \alpha$-ethyl group substituted from chenodeoxycholic acid (CDCA), and has been under intense investigation by Intercept. ${ }^{1,2}$ To date, it has been authorized by Food and Drug Administration for the treatment of primary biliary cholangitis, and granted breakthrough therapy designation in nonalcoholic steatohepatitis. ${ }^{3,4}$ Based on the widespread use of OCA as a FXR agonist in therapeutic applications, the synthesis of OCA has attracted extensive attention. ${ }^{5-7}$ The synthesis strategy of OCA was first focused in Pellicciari et al's report for the introduction of an alkyl substitution from 7-keto-lithocholic acid (Scheme 1). . $^{5,6,8-10}$ However, there are many disadvantage in this process, such as the strict operation with cryogenic temperature, the complicated column purification, the participation of highly toxic reagents including HMPA (hexamethylphosphoramide) and bromoethane, as well as the low overall yield (less than 3.1\%). Similar to this strategy, Yu et al improved the process by using pyridinium chlorochromate (a selective oxidant) and iodoethane (a strong nucleophilic reagent), but did not escape the received

April 19, 2021

accepted

June 3, 2021
DOI https://doi.org/

$10.1055 / \mathrm{s}-0041-1731757$.

ISSN 2628-5088.

\section{(c) 2021. The Author(s).}

This is an open access article published by Thieme under the terms of the Creative Commons Attribution License, permitting unrestricted use, distribution, and reproduction so long as the original work is properly cited. (https://creativecommons.org/licenses/by/4.0/)

Georg Thieme Verlag KG, Rüdigerstraße 14, 70469 Stuttgart, Germany 


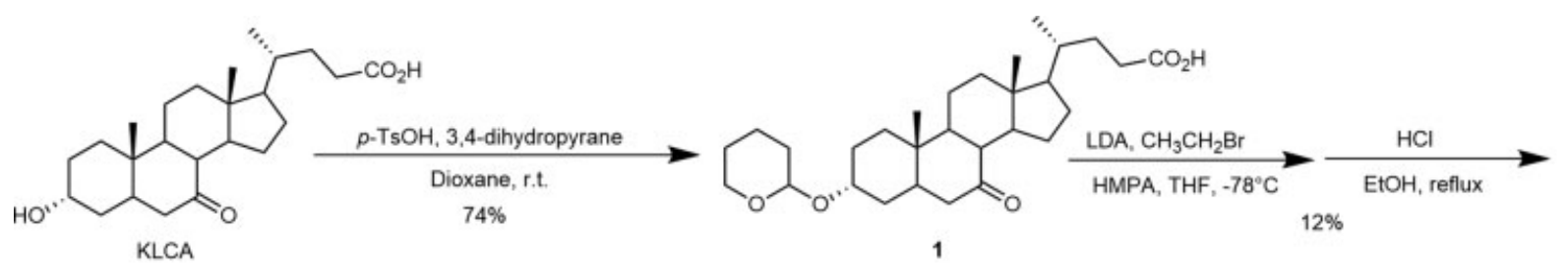

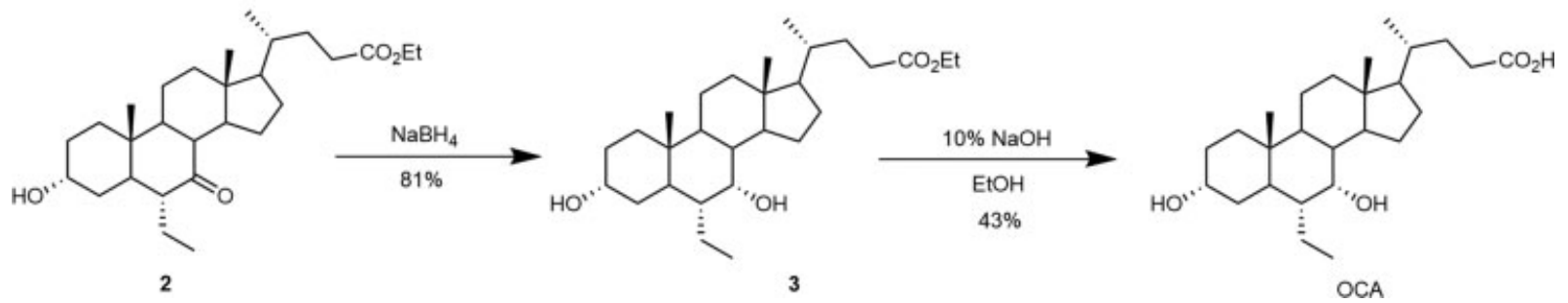

Scheme 1 Alkyl substitution approach to prepare OCA by Pellicciari et al (total yield: 3.1\%). OCA, obeticholic acid.
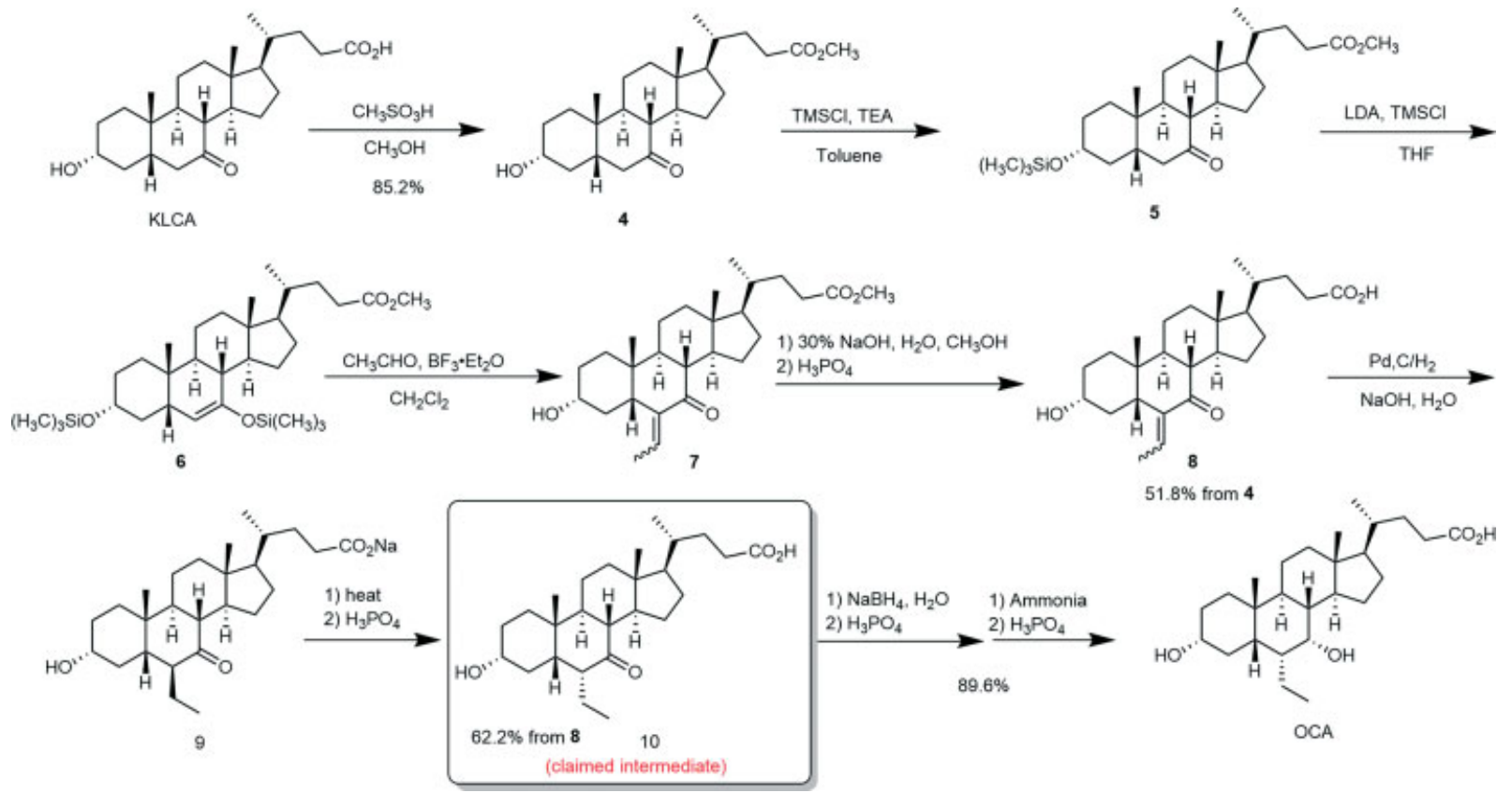

Scheme 2 The first kilogram-scale process illustrated in 8 steps by Ferrari and Pellicciari (total yield: 24.6\%).

use of HMPA and the column chromatograph. ${ }^{11}$ Later, novel synthesis steps of OCA were explored via using cholic acid and 3-keto-bisnorcholenol as starting regents. ${ }^{12,13}$ However, it is difficult to scale up the production of OCA with either approach mentioned above. To our acknowledge, the kilogramscale production of OCA was first reported by Ferrari and Pellicciari in 2006, and this process included eight steps, yet with only $24.6 \%$ total yield achieved (Scheme 2$).{ }^{14}$ It should be noted that $3 \alpha$-hydroxy- $6 \alpha$-ethyl-7-keto-5 $\beta$-cholan-24-oic acid (10), an intermediate from epimerization claimed in a patent, would be converted to OCA with high chiral selectivity after the $\mathrm{NaBH}_{4}$ reduction. In 2013, André et al made the process more safe with high quality and yield (30\%) of OCA being achieved. ${ }^{15}$ Although carcinogenic reagents are avoided and the yield is improved, André et al's process was not concise enough, for example, a large amount of concentrated caustic soda is involved in the reaction independently in the later stage of the process, leading to tedious work and a high amount of waste.

Considering that in compound $\mathbf{1 1}$, a selective reduction of 7-ketone group, priority to 6-ethylene, was obtained (Scheme 3), ${ }^{16}$ protection strategies for functional groups, such as $3 \alpha-\mathrm{OH}$ and $24-\mathrm{COOH}$ (Scheme 4), ${ }^{17-20}$ have aroused much attention during the synthesis of OCA. However, the use of protection strategies would inevitably lead to yield loss and purification challenges as the number of reaction steps being increased. Thus, exploring an effective, concise, and environmentally friendly process to obtain OCA with robust quality control for commercialization remained significantly urgent. ${ }^{21}$

Herein, a novel four-step, telescoped, kilogram-scale process to obtain OCA was discovered. The E-conformation of 8 (8-E), a commercially available agent, was used as the key staring material (Scheme 5). Instead of double blocking, only 


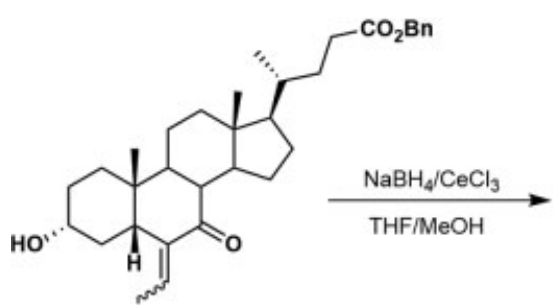

11

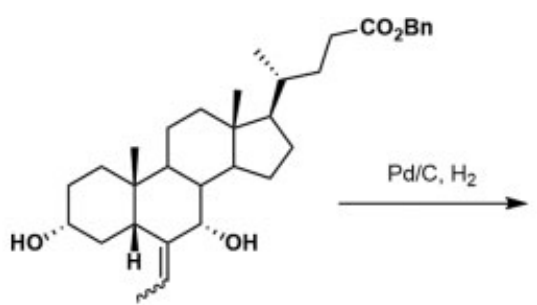

12

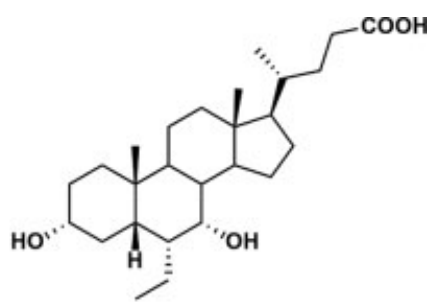

OCA

Scheme 3 Alternative strategy by reducing 7-ketone priority to hydrogenation by Sepe et al.

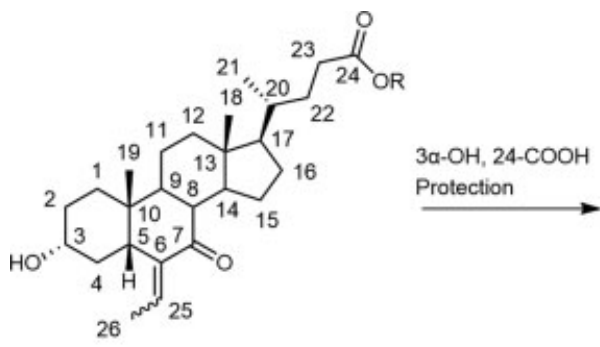

$\mathrm{P}=$ THP, MOM (base tolerant but acid labile)

$\mathrm{R}=\mathrm{Me}, \mathrm{Et}, \mathrm{Bn}$

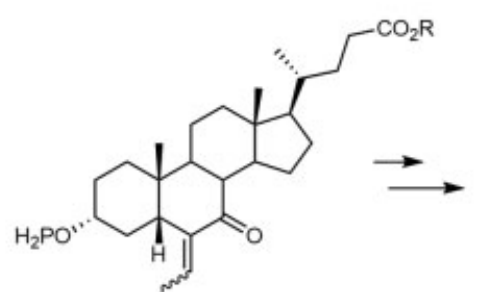

more steps with more purification challenges

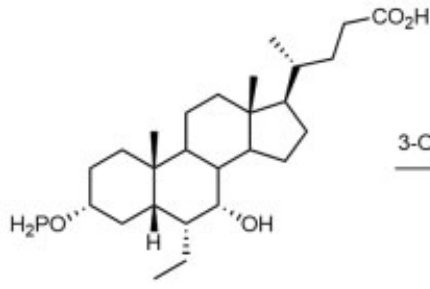

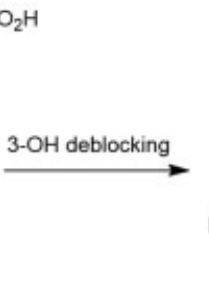<smiles>CC[C@H]1C(O)[C@H]2CCC([C@H](C)CCC(=O)O)C2(C)CCC12CCC(O)CC2</smiles>

OCA

Scheme 4 Double blocking strategy for $3 \alpha-\mathrm{OH}$ and $24-\mathrm{COOH}$.

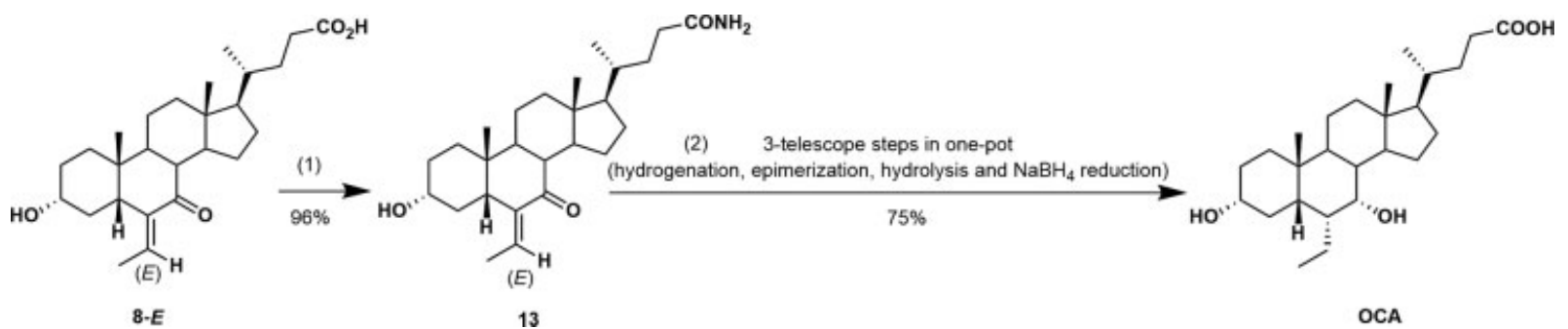

Scheme 5 Telescoped process of OCA in this study. (1) $\mathrm{NH}_{4} \mathrm{Cl}$, PyBOP, DMF, DIPEA, $0^{\circ} \mathrm{C}$-r.t.. (2) $\mathrm{H}_{2}, 10 \% \mathrm{Pd} / \mathrm{C}, \mathrm{MeOH}, 50^{\circ} \mathrm{C}, 4$ atm; then $\mathrm{NaOH}$, $\mathrm{H}_{2} \mathrm{O}$, reflux; followed with $\mathrm{NaBH}_{4}$, reflux. OCA, obeticholic acid.

the $24-\mathrm{COOH}$ of $\mathbf{8}-\mathbf{E}$ was protected as amide $\mathbf{1 3}$, which was converted to OCA in a one-pot procedure integrating the previous strong base steps. ${ }^{14,15}$ Besides, variant process parameters, including the final recrystallization condition, were further investigated, and high-quality OCA with satisfactory yield was successfully obtained.

\section{Results and Discussion}

Compound 8-E was Preferred as the Starting Material Compound $\mathbf{8}$ is a crude mixture of $E / Z$ isomers with no fixed proportion (Scheme $\mathbf{2}$ ). When $\mathbf{8}$ was coupled with $\mathrm{NH}_{4} \mathrm{Cl}$, crude 13 was obtained as a mixture of $E / Z$ isomers with only $70 \%$ yield. Given above, the $E$-isomer of 8 (8-E), instead of $\mathbf{8}$, was preferred for the following reasons: (1) $\mathbf{8}-\boldsymbol{E}$ is commercially available at a cheap price

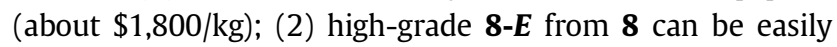
achieved through recrystallization (-Fig. 1) ${ }^{15}$ with both the E-isomer ratio and purity being no less than $99.0 \%$, and the specified impurity (7-ketolithocholic acid associated with CDCA) being NMT (no more than) $0.2 \%$; and (3) ultraviolet (UV) absorption of $\mathbf{8 - E}$ is strong, making it easier to monitor the target compounds.

\section{Preparation of (E)-3 $\alpha$-Hydroxy-6-ethylidene-7-keto- 5ß-cholan-24-amide (13, Step 1)}

We prepared $\mathbf{1 3}$ from 8-E through an amidation reaction, and the process parameter is outlined in - Table 1. In this 

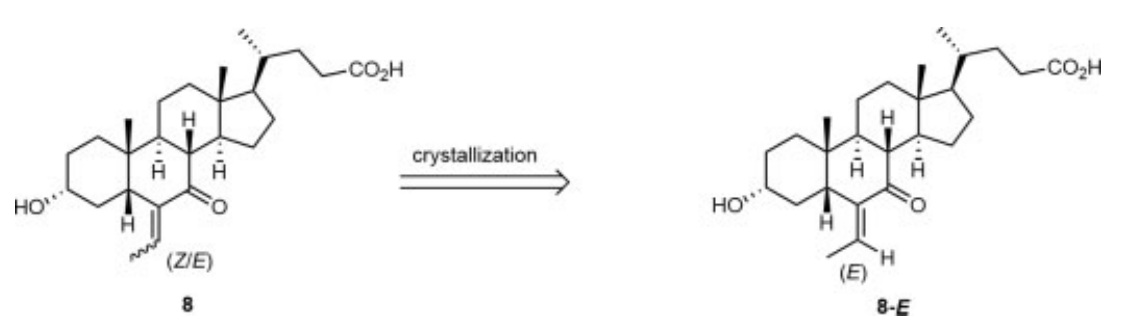

Fig. 1 8-E could crystallize from configuration mixed 8.

process, amine $\mathrm{NH}_{4} \mathrm{Cl}$ was preferred, as it was identified to be cost-effective, and to have reliable stability and safety. Through using $\mathrm{NH}_{4} \mathrm{Cl}$, compound 13 could separate, as an excellent solid, in nearly quantitative yield, and the subsequent hydrolyses could be completed with least impurities in comparison to other amides. For example, the separated yield of target amides consisted of morpholine (80\%, entry 3), $\mathrm{CH}_{3} \mathrm{ONH}_{2} \cdot \mathrm{HCl}(79 \%$, entry 4), and $\mathrm{CH}_{3} \mathrm{NHOCH}_{3} \cdot \mathrm{HCl}(77 \%$, entry 6$)$, and these amounts of yields were much lower than that of $\mathrm{NH}_{4} \mathrm{Cl}$ (96\%, Entry 8 ). It is exciting to notice that the yield of the target product was good when using $\mathrm{CH}_{3} \mathrm{NH}_{2} \cdot \mathrm{HCl}$ (90\%, entry 1 ) and pyrrolidine (92\%, entry 2). However, the use of pyrrolidine, originated from PyBOP, resulted in the generation of pyrrolidide byproduct 14, the major product in this reaction (- Fig. 2). ${ }^{22}$ Besides, by using $\mathrm{CH}_{3} \mathrm{NH}_{2} \cdot \mathrm{HCl}$ and pyrrolidine, the resulting amides were too stable to hydrolyze in the following one-pot procedure, leading to increased impurities of OCA, and thus, neither of them was used in this synthesis step. Furthermore, the use of $\mathrm{HONH}_{2} \cdot \mathrm{HCl}$ led to yield loss of the target product $(87 \%$, entry 5) and 5\% yield of 7-oxime byproduct, yet $\mathrm{CH}_{3} \mathrm{NHOH} \cdot \mathrm{HCl}$ gave a messier coupling result (entry 7).

PyBOP was employed as a coupling reagent according to a reported study. ${ }^{23}$ Our data showed that PyBOP resulted in a higher consumption and less impurities (entry 8, 8-E consumed over in 6 hours, $96 \%$ yield) when compared with HBTU (entry $10,8-\boldsymbol{E}$ consumed over in 24 hours, three impurities with $2-5 \%$ content), EDCI/1-hydroxybenzotriazole (HOBt)(entry $11,6 \%$ 8-E left after 36 hours), or DIC (entry $12,25 \%$ 8-E left after 24 hours). Hünig's base was beneficial for time-saving and complete consumption in comparison to triethylamine (entry 9, 10\% 8-E left after 24 hours). With the optimized conditions in hand, compound $\mathbf{1 3}$ was obtained in good yield (96\%, entry 8) with high-performance liquid chromatography (HPLC) purity $>98 \%$, which was confirmed with ${ }^{1} \mathrm{HNMR},{ }^{13} \mathrm{C}$ NMR, and HRMS (high-resolution mass spectrometry) spectra. The selected coupling conditions were found to perform well in a kilogram-scale production with a good yield of $96 \%$.

Under the reaction conditions provided in - Table 1, five major byproducts were confirmed in this step, and they were $Z$-isomer (13-Z), pyrrolidine amide (14), self-esterified dimer (15), tri(pyrrolidin-1-yl)phosphine oxide (16), as well as HOBt.

\section{Preparation of OCA through the One-Pot Procedure (Steps 2-4)}

Telescoped synthesis of OCA from compound $\mathbf{1 3}$ is shown in -Fig. 3. The procedure started with $\mathrm{Pd} / \mathrm{C}$ catalytic hydrogenation (step 2) and epimerization (step 3), followed by $\mathrm{NaBH}_{4}$-induced reduction (step 4). Hydrolysis of the amide unit proceeded in both step 3 and step 4. In step 2, the reaction conditions were screened. Based on the fact that the solvent should not only dissolve the substrate effectively but also be mutually soluble with water, several solvents, including methanol, dichloromethane, dioxane, tetrahydrofuran, or a combination of the above solvents, have been selected. In this step, single solvent methanol (methanol:13 =12:1, v/m) was preferred, despite a better dissolvability of $\mathbf{1 3}$ in a binary solvent of methanol and dichloromethane (1:1). Noticeably, blockages tend to occur during filtration when using the two hydrophobic solvents. Furthermore, to favor fast consumption (controlling 13 NMT $0.2 \%)$, pressure $(3-5 \mathrm{~atm})$ and heat $\left(40-55^{\circ} \mathrm{C}\right)$ were also employed. In this step, a mixture of $\mathbf{1 7} \boldsymbol{\alpha} / \mathbf{1 7} \boldsymbol{\beta}$ isomers (the ratio is close to $10: 90$ ) was obtained with no further filtration, since the isomeric intermediates precipitated quickly after slight cooling of this reaction.

Once $\mathrm{NaOH}$ solution was charged to the hydrogenation tan, epimerization along with hydrolysis (step 3) immediately started under the condition of reflux. In this step, only the residue of $\mathbf{1 7} \boldsymbol{\alpha}$ was monitored (17 $\alpha$ is controlled NMT $1 \%)$. Amide hydrolysis should be ignored because the further hydrolysis may continue during the $\mathrm{NaBH}_{4}$ reduction (Step 4). Thus, the dosage of $\mathrm{NaOH}$ and $\mathrm{NaBH}_{4}$ was screened in the following study. - Table 2 notes that $\mathrm{NaOH}$ (20 equiv.: the molar ratio to $\mathbf{1 3}$ is 20$) / \mathrm{NaBH}_{4}$ (2.0 equiv.) was the best formula (entry 5) with less 7-ketone intermediates left. Low base ability (entries 6 and 7) was associated with inadequate hydrolysis, resulting in retainment of amide-blocked impurities (e.g., 18 $\alpha$ and $\mathbf{1 8 \beta}, 2-8 \%, \alpha$-conformation is the major). Furthermore, a low amount of $\mathrm{NaBH}_{4}$ (entries 2 and 3, 1.5 equiv. and 1.0 equiv.) brought byproducts with 7-ketone reserved (10 or Imp-6 is the major with the yield of $6-11 \%)$. Although the full consumption of the starting material $\mathbf{1 0}$ and the high quality of the target product being obtained, the use of $\mathrm{NaOH}$ (entry 4, 30 equiv.) or $\mathrm{NaBH}_{4}$ (entry $1,3.0$ equiv.) should be given up because of the overwastage that occurred.

\section{Crystallization for the Final Purification of Crude OCA}

Once the final in process control (10 is controlled below 1.0\%) passed, a routine work-up procedure, including acid quenching, extraction, and distillation, was performed. The purity of the crude product is close to $95 \%$ with Imp-1 as the major impurity ( 4\%). The final purification of OCA is crucial for furnishing qualified active pharmaceutical ingredient. 
Table 1 Coupling condition screened for intermediate 13 (solvent: DMF)

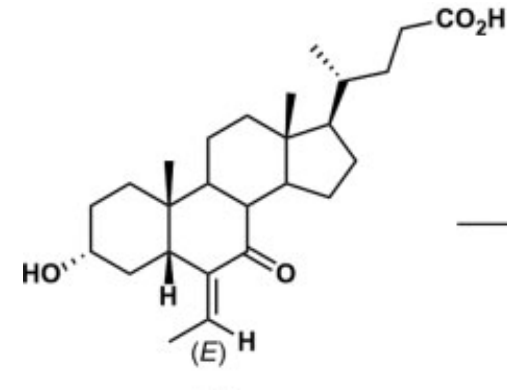

8-E

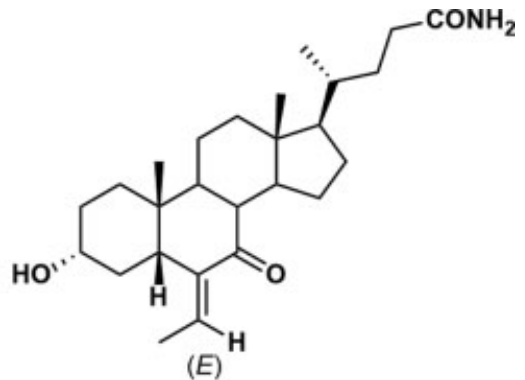

13

\begin{tabular}{|c|c|c|c|c|c|c|}
\hline Entry & Amine & $\begin{array}{l}\text { Coupling } \\
\text { reagent }\end{array}$ & Base & $\begin{array}{l}\text { Consumption, quality and } \\
\text { work-up }\end{array}$ & Yield & $\begin{array}{l}\text { Impact of the resulting } \\
\text { amide on one-pot step }\end{array}$ \\
\hline 1 & $\mathrm{CH}_{3} \mathrm{NH}_{2} \cdot \mathrm{HCl}$ & РуВOP & DIPEA & $\begin{array}{l}\text { Consumed over in } 6 \text { hours, } \\
\text { solid formed }\end{array}$ & $90 \%$ & $\begin{array}{l}\text { Hardly to hydrolyze, } \\
\text { much messier than entry } 8\end{array}$ \\
\hline 2 & Pyrrolidine & РуВOP & DIPEA & $\begin{array}{l}\text { Consumed over in } 6 \text { hours, } \\
\text { solid formed }\end{array}$ & $92 \%$ & $\begin{array}{l}\text { Hardly to hydrolyze, } \\
\text { much messier than entry } 8\end{array}$ \\
\hline 3 & Morpholine & РyBOP & DIPEA & $\begin{array}{l}\text { Consumed over in } 6 \text { hours, } \\
\text { foam, need extraction }\end{array}$ & $80 \%$ & $\begin{array}{l}\text { Most amide hydrolyze, } \\
\text { much messier than entry } 8\end{array}$ \\
\hline 4 & $\mathrm{CH}_{3} \mathrm{ONH}_{2} \cdot \mathrm{HCl}$ & РуВОР & DIPEA & $\begin{array}{l}\text { Consumed over in } 6 \text { hours, } \\
\text { foam, need extraction }\end{array}$ & $79 \%$ & Trace product, messy \\
\hline 5 & $\mathrm{HONH}_{2} \cdot \mathrm{HCl}$ & РуВOР & DIPEA & $\begin{array}{l}\text { Consumed over in } 6 \text { hours, } \\
\text { oxime byproduct ( } 5 \%) \text {, solid } \\
\text { formed }\end{array}$ & $87 \%$ & Similar to entry 8 \\
\hline 6 & $\begin{array}{l}\mathrm{CH}_{3} \mathrm{NHOCH}_{3} \cdot \mathrm{H}- \\
\mathrm{Cl}\end{array}$ & РуВOP & DIPEA & $\begin{array}{l}\text { Consumed over in } 6 \text { hours, } \\
\text { foam, need extraction }\end{array}$ & $77 \%$ & Similar to entry 8 \\
\hline 7 & $\mathrm{CH}_{3} \mathrm{NHOH} \cdot \mathrm{HCl}$ & РyBOP & DIPEA & $\begin{array}{l}\text { Consumed over in } 6 \text { hours, a } \\
\text { major impurity (11\%) }\end{array}$ & ND & 1 \\
\hline 8 & $\mathrm{NH}_{4} \mathrm{Cl}$ & РуВОР & DIPEA & $\begin{array}{l}\text { Consumed over in } 6 \text { hours, } \\
\text { solid formed }\end{array}$ & $96 \%$ & $\begin{array}{l}\text { Least impurities, } \\
\text { quality in control. }\end{array}$ \\
\hline 9 & $\mathrm{NH}_{4} \mathrm{Cl}$ & РуВOP & TEA & $10 \% 8-E$ stayed after 24 hours & ND & 1 \\
\hline 10 & $\mathrm{NH}_{4} \mathrm{Cl}$ & HBTU & DIPEA & $\begin{array}{l}\text { Consumed over in } 24 \text { hours, } \\
3 \text { impurities }(2-5 \%)\end{array}$ & ND & 1 \\
\hline 11 & $\mathrm{NH}_{4} \mathrm{Cl}$ & $\mathrm{EDCl} / \mathrm{HOBt}$ & DIPEA & $6 \% 8-E$ stayed after 36 hours & ND & 1 \\
\hline 12 & $\mathrm{NH}_{4} \mathrm{Cl}$ & DIC & DIPEA & $25 \% 8-E$ stayed after 24 hours & ND & 1 \\
\hline
\end{tabular}

André et al highlighted the participation of $n$-butyl acetate ( $n$-BuOAc) in OCA recrystallization. ${ }^{15}$ Feng et al suggested the potential use of heptane as a wonderful antisolvent in this process. ${ }^{24}$ In this study, the crystallization conditions were screened based on the ratio of $n$-BuOAc/heptane ( - Table $\mathbf{3}$, entries 1-5), and we further proposed a two-stage cooling plan for OCA recrystallization: at first warm crystallization was used to control the quality, then a cooler precipitation was performed to get more product (-Table 3, entries 5-7). With the optimized recrystallization conditions, the quality and yield of OCA significantly improved (entries 6 and 7; 77 and $75 \%$, respectively). In comparison to second cooling to $10^{\circ} \mathrm{C}$, the second cooling to $20^{\circ} \mathrm{C}$ led to less Imp-1 (the maximum impurity: $0.24 \%$ in entry $6 ; 0.08 \%$ in entry 7 ), and should be chosen as the ideal crystallization conditions. In this article, the final crystallization procedure was confirmed as follows: OCA crude was dissolved in a binary solvent of $n$-BuOAc: heptane (4.4:0.85), and then refluxed; the clear solution was gradually cooled down to $40^{\circ} \mathrm{C}$ with the cooling rate being 8 to $15^{\circ} \mathrm{C}$ /hour for warm crystallization for $\sim 2$ hours, followed by a second cooling at a similar rate to $20^{\circ} \mathrm{C}$, and the system was held for further precipitation.

After this process of crystallization, a similar impurity profile involving three isomers (Imp-1, 2, and 3), CDCA (Imp-4), and the dimer (Imp-9) was outlined as disclosed (-Fig. 4). ${ }^{15,24}$ Two exclusive impurities, Imp-5 (originated from pyrrolidine) and Imp-8 (originated from methanol), were rarely detected. Imp-6 and Imp-7 were generated via the insufficient reduction for the 7-ketone or 6-ethylene group, while Imp-10 was the residue of 8-E. As OCA and most impurities have poor UV absorption for detection, the HPLC-charged aerosol detector (CAD) method was introduced covering all the above impurities in acceptable resolution (Figure S11 [online only]). Our data suggested a $>99.5 \%$ purity of OCA from a kilogram-scale campaign, and all impurities were controlled NMT $0.10 \%$, which was in 


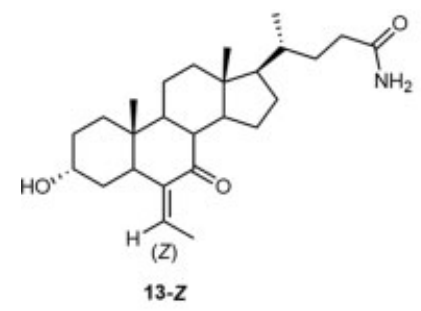<smiles>On1nnc2ccccc21</smiles><smiles>CC([PH3+])=C1C(=O)C2C([C@H](C)CCC(=O)N3CCCC3)CCC2[C@]2(C)CC[C@H]1C1C[C@H](O)CCC12C</smiles>

14 originated from the existing of pyrrolidine in PyBOP
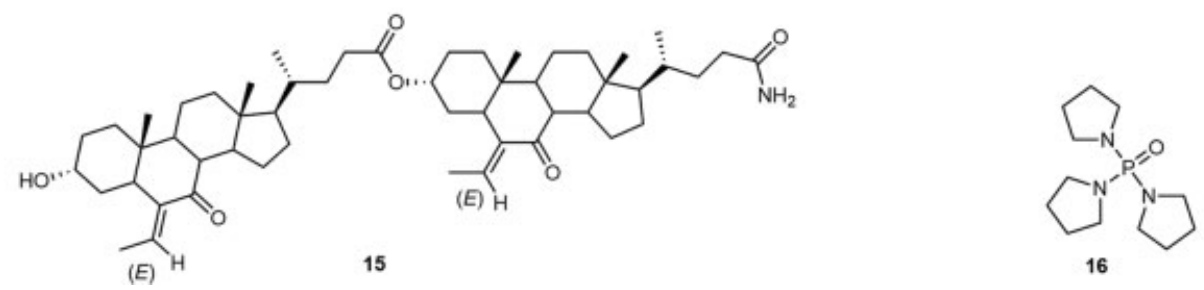

Fig. 2 Possible byproducts in amide-coupling reaction.

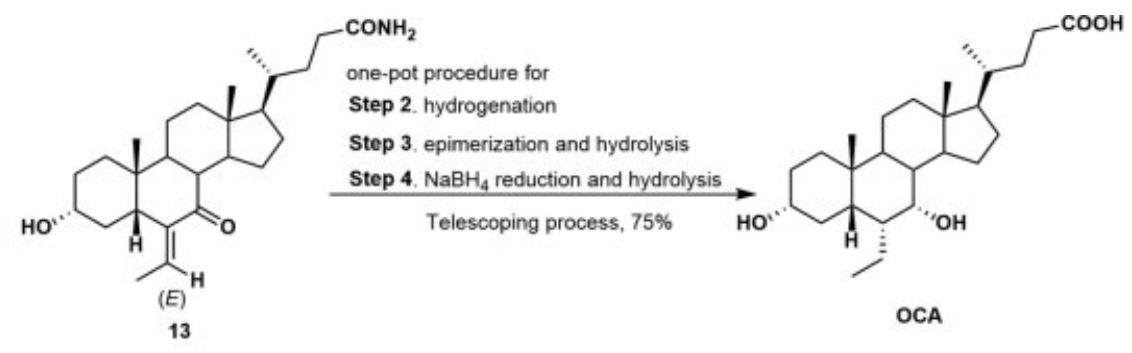

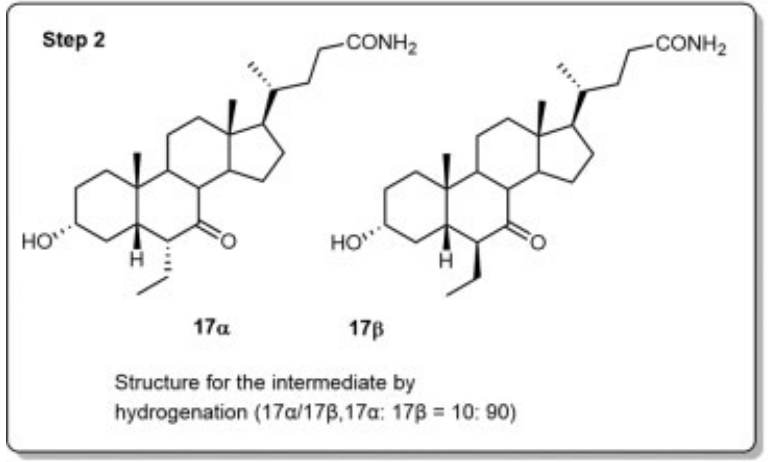

Fig. 3 Telescoped production of OCA. OCA, obeticholic acid.

accordance with the ICH (International Council for Harmonisation of Technical Requirements for Pharmaceuticals for Human Use) guideline, and more stricter than that of the documented process (-Table 4), ${ }^{25}$ especially for Imp-4 and Imp-9 (both were less than $0.05 \%$ in comparison to controlled NMT $0.15 \%$ and $3.0 \%$ in the documented process, respectively). ${ }^{15}$ This could be attributed to the strict quality precontrol in $\mathbf{8 - E}$ and the use of complete hydrolysis as an adequate base.

\section{Conclusion}

In summary, the production of OCA, without the need of separating intermediate $\mathbf{1 0}$, was achieved in a four-step process, including three-telescoped steps in one pot integrating previous multiple steps. ${ }^{26}$ Key to the process is the selection of amide $\mathbf{1 3}$ as a key intermediate obtained by coupling 8-E (a cheap commercially available regent) with $\mathrm{NH}_{4} \mathrm{Cl}$ in the presence of PyBOP and DIPEA, which is easily purified and performed well for the one-pot procedure. Process parameters including the solvent, the ratio of reagents $\left(\mathrm{NaOH}\right.$ and $\mathrm{NaBH}_{4}$ ), and recrystallization conditions (solvent and the cooling control) were thoroughly studied for optimum yield, safety, and quality considerations. An effective HPLC-CAD method was also introduced to determine the purity of the final crystals. A kilogram-scale production following this process succeeded to furnish the desired product in $72 \%$ overall yield and over $99.5 \%$ purity, while 
Table 2 The ratio screen of $\mathrm{NaOH}$ and $\mathrm{NaBH}_{4}$ for this one-pot process

\begin{tabular}{|c|c|c|c|}
\hline Entry & $\mathrm{NaOH}$ & $\mathrm{NaBH}_{4}$ & $\begin{array}{l}\text { The quality of the } \\
\text { crude product }\end{array}$ \\
\hline 1 & 20 equiv. & 3.0 equiv. & $\begin{array}{l}0.15 \% \text { of } 7-\text { ketone } \\
\text { intermediate } 10 \text { stayed }\end{array}$ \\
\hline 2 & 20 equiv. & 1.5 equiv. & $\begin{array}{l}\text { 6\% of 7-ketone interme- } \\
\text { diate } 10 \text { stayed }\end{array}$ \\
\hline 3 & 20 equiv. & 1.0 equiv. & $\begin{array}{l}11 \% \text { of } 7 \text {-ketone } \\
\text { intermediate } 10 \text { stayed }\end{array}$ \\
\hline 4 & 30 equiv. & 2.0 equiv. & $\begin{array}{l}\text { Little amide intermediate } \\
\text { stayed }\end{array}$ \\
\hline 5 & 20 equiv. & 2.0 equiv. & $\begin{array}{l}0.2 \% \text { of amide intermedi- } \\
\text { ate ( } 18 \alpha \text { is the major), } \\
0.13 \% \text { of } 7 \text {-ketone inter- } \\
\text { mediate } 10 \text { stayed }\end{array}$ \\
\hline 6 & 10 equiv. & 2.0 equiv. & $\begin{array}{l}2 \% \text { of amide intermediate } \\
\text { ( } 18 \alpha \text { is the major) and } \\
\text { obvious pyrrolidine-cou- } \\
\text { pled amide stayed }\end{array}$ \\
\hline 7 & 5 equiv. & 2.0 equiv. & $\begin{array}{l}8 \% \text { of amide intermediate } \\
(18 \alpha: 18 \beta=12.5: 1) \text { and } \\
\text { much pyrrolidine-coupled } \\
\text { impurities formed }\end{array}$ \\
\hline
\end{tabular}

total impurities were well below $0.10 \%$. This process is not only concise but also environmentally friendly, scalable, and shows excellent quality control.

\section{Supporting Information}

Spectroscopic characterization processes $\left({ }^{1} \mathrm{H}\right.$ NMR, ${ }^{13} \mathrm{C}$ NMR, and HRMS) for 13 and OCA, as well as HPLC-CAD results for the possible impurities following OCA synthesis, are included in the -Supporting Information (Figs. S1-11 [online only]).

\section{Experimental Section}

\section{General}

Common reagent-grade chemicals such as PyBOP and $\mathrm{NH}_{4} \mathrm{Cl}$ were purchased and used without further purification. The key starting material 8-E was supplied by Xiamen Halosyntech Co., Ltd.. The ${ }^{1} \mathrm{H}$ NMR and ${ }^{13} \mathrm{C}$ NMR spectra data were recorded either on a Bruker $600 \mathrm{MHz}$ or a Bruker $400 \mathrm{MHz}$ NMR spectrometer. Chemical shifts are summarized in parts per million (ppm) using tetramethylsilane as an internal standard and are given in $\delta$ units. Solvents for NMR spectra were DMSO- $d_{6}$ or $\mathrm{CD}_{3} \mathrm{OD}$ unless otherwise stated. Highresolution mass spectra were obtained on an Agilent 1100 series HPLC system coupled to an Agilent 6210 ESI-TOF mass spectrometer. The purity of OCA was analyzed on a Thermo Fisher Dionex Ultimate 3000 system with Corona Veo CAD, chromatographic separation was performed on an Agilent InfinityLab Poroshell column at a flow rate of $0.6 \mathrm{~mL} /$ minute for a run time of 45 minutes. The mobile phase $A$ was $0.1 \%$ formic acid ( $\mathrm{v} / \mathrm{v})$ and the mobile phase $\mathrm{B}$ was acetonitrile.

\section{General Procedure for the Synthesis of (E)-3a-Hydroxy-6-} ethylidene-7-keto-5 $\beta$-cholan-24-amide (compound 13)

A $100 \mathrm{~L}$ glass tank was charged with $8-E(4.80 \mathrm{~kg}), \mathrm{N}, \mathrm{N}-$ dimethylformamide $(32.10 \mathrm{~kg})$, and PyBOP $(7.25 \mathrm{~kg})$ at ice temperature. After that, DIPEA $(5.95 \mathrm{~kg})$ was added slowly, the mixture was stirred for 30 minutes, followed by the addition of ammonium chloride $(1.00 \mathrm{~kg})$. The content of 8-E in the process was monitored by HPLC (NMT 0.5\%), and then $5 \%$ sodium bicarbonate solution was added dropwise. After stirring for another 1 hour, the mixture was centrifuged and washed twice with water. The wet cake (containing $\sim 50 \%$ water $)$ was dissolved in ethyl acetate $(25.90 \mathrm{~kg})$ and refluxed for another 1 hour. After cooling down, the solid product was routinely centrifuged, washed twice with water, and then dried in an air-drying oven at 55 to $60^{\circ} \mathrm{C}$ to yield the title compound as off-white powder $(4.60 \mathrm{~kg}$, yield: $96 \%$,

Table 3 Crystallization condition screen for the purification of OCA

\begin{tabular}{|c|c|c|c|c|c|c|}
\hline Entry & $\begin{array}{l}n-\mathrm{BuOAc} \\
(\mathrm{v} / \mathrm{m})\end{array}$ & $\begin{array}{l}\text { Heptane } \\
(\mathrm{v} / \mathrm{m})\end{array}$ & Temp. control and crystallization state & $\begin{array}{l}\text { Crystal } \\
\text { purity }\end{array}$ & $\operatorname{Imp}-1^{a}$ & Yield \\
\hline 1 & 3.5 & 0 & $\begin{array}{l}\text { Reflux to } 25^{\circ} \mathrm{C} \text { naturally, smooth } \\
\text { crystallization }\end{array}$ & $99.8 \%$ & $0.07 \%$ & $56 \%$ \\
\hline 2 & 2.0 & 0 & Reflux to $25^{\circ} \mathrm{C}$ naturally, too thick to filtration & 1 & 1 & 1 \\
\hline 3 & 2.7 & 0.85 & $\begin{array}{l}\text { Reflux to } 25^{\circ} \mathrm{C} \text { with fast cooling, thick crystals } \\
\text { formed dramatically with separation trouble }\end{array}$ & $98.6 \%$ & $0.65 \%$ & $84 \%$ \\
\hline 4 & 4.0 & 0.85 & $\begin{array}{l}\text { Reflux to } 30^{\circ} \mathrm{C} \text { with fast cooling, thick crystals } \\
\text { formed dramatically with separation trouble }\end{array}$ & $99.1 \%$ & $0.37 \%$ & $74 \%$ \\
\hline 5 & 4.4 & 0.85 & $\begin{array}{l}\text { Reflux to } 40^{\circ} \mathrm{C} \text { naturally, smooth } \\
\text { crystallization }\end{array}$ & $99.7 \%$ & $0.07 \%$ & $62 \%$ \\
\hline 6 & 4.4 & 0.85 & $\begin{array}{l}\text { Reflux to } 35^{\circ} \mathrm{C} \text { (hold on for } 2 \text { hours), second } \\
\text { cooling to } 10^{\circ} \mathrm{C} \text {, smooth crystallization }\end{array}$ & $99.2 \%$ & $0.24 \%$ & $77 \%$ \\
\hline 7 & 4.4 & 0.85 & $\begin{array}{l}\text { Reflux to } 40^{\circ} \mathrm{C} \text { (hold on for } 2 \text { hours), second } \\
\text { cooling to } 20^{\circ} \mathrm{C} \text {, smooth crystallization }\end{array}$ & $99.6 \%$ & $0.08 \%$ & $75 \%$ \\
\hline
\end{tabular}

amp-1 was the maximum impurity in this process. 


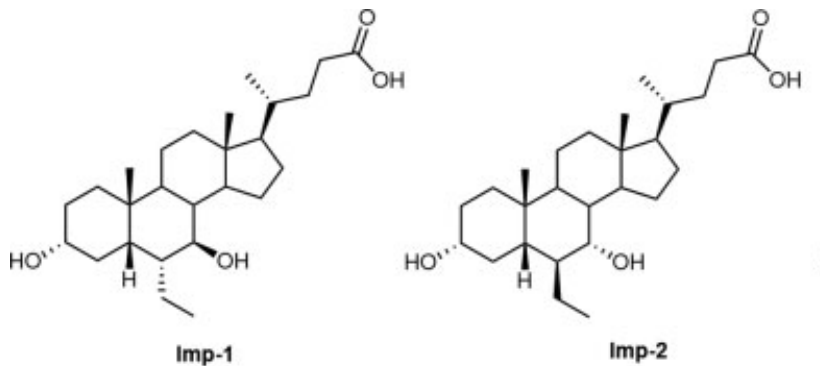

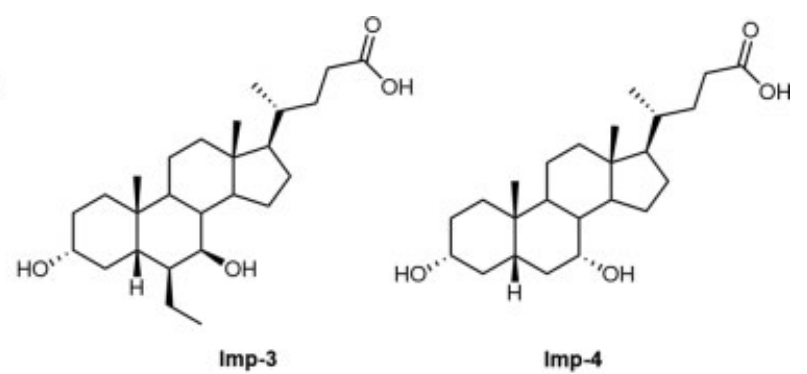

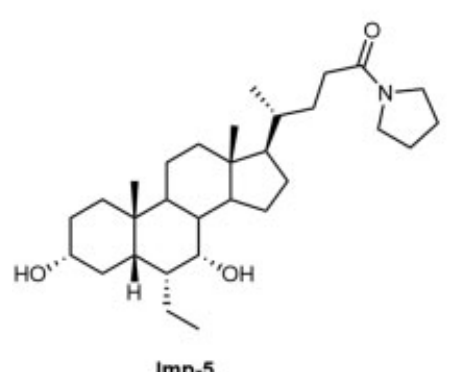<smiles></smiles>

Imp-6(10)

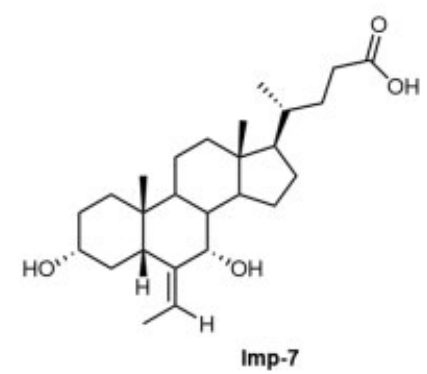

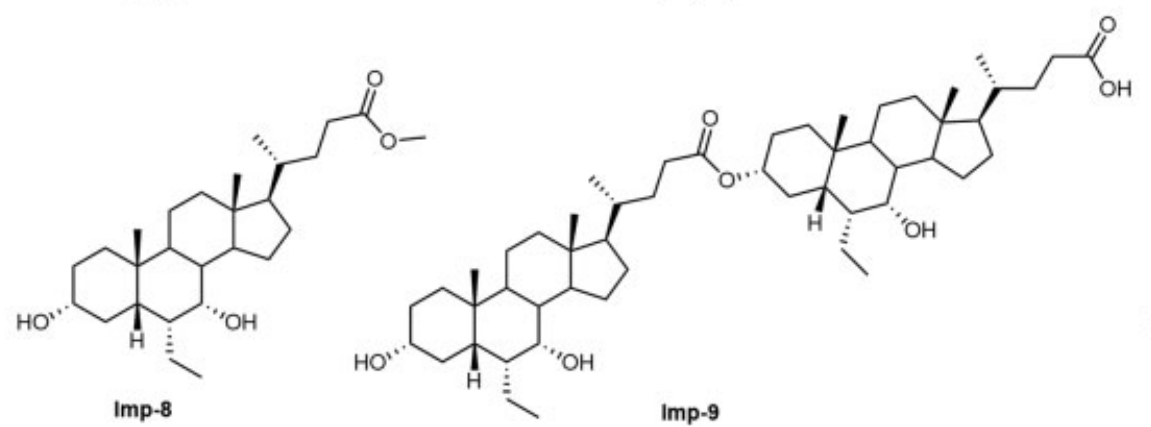

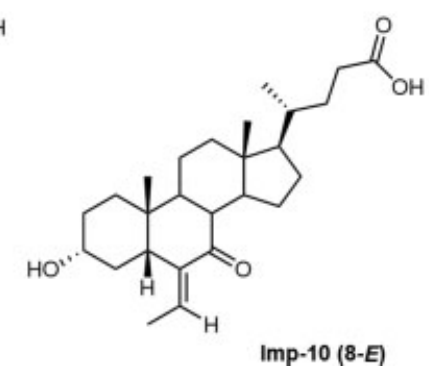

Fig. 4 Related substances after the crystallization.

HPLC purity: 98.2\%). ${ }^{1} \mathrm{H}$ NMR (600 MHz, DMSO- $\left.d_{6}\right) \delta 7.23$ $(\mathrm{s}, 1 \mathrm{H}), 6.66(\mathrm{~s}, 1 \mathrm{H}), 5.97(\mathrm{q}, J=7.2,13.8 \mathrm{~Hz}, 1 \mathrm{H}), 4.55(\mathrm{~d}$, $J=4.8 \mathrm{~Hz}, 1 \mathrm{H}), 3.46-3.42(\mathrm{~m}, 1 \mathrm{H}), 2.60-2.57(\mathrm{~m}, 1 \mathrm{H})$, 2.30-2.25 (m, 1H), $2.20(\mathrm{t}, J=11.4 \mathrm{~Hz}, 1 \mathrm{H}), 2.09-2.04(\mathrm{~m}$, $1 \mathrm{H}), 1.97-1.79(\mathrm{~m}, 5 \mathrm{H}), 1.68-1.64(\mathrm{~m}, 4 \mathrm{H}), 1.57-1.55(\mathrm{~m}, 1 \mathrm{H})$, 1.44-1.31 (m, 5H), 1.25-1.02 (m, 8H), $0.94(\mathrm{~s}, 3 \mathrm{H}), 0.89$ (d, $J=6.0 \mathrm{~Hz}, 3 \mathrm{H}), 0.60(\mathrm{~s}, 3 \mathrm{H}) .{ }^{13} \mathrm{C}$ NMR $(150 \mathrm{MHz}$, DMSO$\left.d_{6}\right) \delta 203.72,174.70,143.69,128.34,68.57,54.09,50.26$, $48.18,44.88,43.05,38.59,38.50,37.55,34.83,34.20,34.03$, $32.05,31.44,29.60,28.00,25.65,22.59,20.86,18.45,12.32$, 11.88. HRMS $m / z$ calcd. for $\mathrm{C}_{26} \mathrm{H}_{42} \mathrm{NO}_{3}[\mathrm{M}+\mathrm{H}]^{+} 416.3159$, found 416.3157; calcd. for $\mathrm{C}_{26} \mathrm{H}_{41} \mathrm{NNaO}_{3}[\mathrm{M}+\mathrm{Na}]$ 438.2979, found 438.2976 .

\section{General Procedure for the Synthesis of $3 \alpha, 7 \alpha-$}

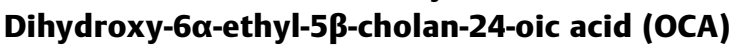

To a solution of $13(4.19 \mathrm{~kg})$ in methanol $(39.81 \mathrm{~kg})$ in a $200 \mathrm{~L}$ high-pressure tank, $10 \%$ wet palladium on carbon $(0.94 \mathrm{~kg})$ was added after flushing with $\mathrm{N}_{2}$. Afterwards, the gas was exchanged with $\mathrm{H}_{2}$, the mixture was stirred at $50^{\circ} \mathrm{C}$ at a pressure of $4 \mathrm{~atm}$ until 13 was NMT $0.2 \%$. To the mixture, sodium hydroxide solution $(8.00 \mathrm{~kg}$ sodium hydroxide in $50.28 \mathrm{~kg}$ water) was added, and then refluxed for 3 hours until $17 \alpha$ was NMT $1.0 \%$. The resulting solution was filtrated and washed with water $(2 \mathrm{~kg} \times 2)$, the filtrate was added sodium borohydride $(0.76 \mathrm{~kg})$ portion-wise, refluxed for another 6 hours, and cooled down. For the resulting mixture,

Table 4 Comparison of the controlling strategy of related substances between this process and documented process ${ }^{12}$

\begin{tabular}{|l|l|l|l|l|l|l|l|l|l|l|}
\hline Entry & Imp-1 & Imp-2 & Imp-3 & Imp-4 & Imp-5 & Imp-6 & Imp-7 & Imp-8 & Imp-9 & Imp-10 \\
\hline Documented process limit & $0.15 \%$ & $0.15 \%$ & $\mathrm{NA}^{\mathrm{a}}$ & $3.0 \%$ & $\mathrm{NA}$ & $0.15 \%$ & $0.15 \%$ & $\mathrm{NA}$ & $0.15 \%$ & $\mathrm{NA}$ \\
\hline This process limit & $0.15 \%$ & $0.10 \%$ & $0.10 \%$ & $0.10 \%$ & $0.10 \%$ & $0.10 \%$ & $0.10 \%$ & $0.10 \%$ & $0.10 \%$ & $0.10 \%$ \\
\hline Resolution & 1.46 & 6.25 & 2.07 & 5.71 & 26.90 & 8.55 & 1.46 & 40.11 & $/$ & 8.88 \\
\hline Assay in a kilogram-scale production & $0.08 \%$ & $0.02 \%$ & $\mathrm{ND}^{\mathrm{b}}$ & $0.04 \%$ & $0.04 \%$ & $\mathrm{ND}$ & 0.03 & 0.02 & $0.03 \%$ & $\mathrm{ND}$ \\
\hline
\end{tabular}

aNA refers to "not analyzed."

${ }^{\mathrm{b}} \mathrm{ND}$ refers to "not detected." 
the $\mathrm{pH}$ was adjusted to $\mathrm{pH} 4-5$ with hydrochloride $(21.61 \mathrm{~kg})$ and then it was neutralized with sodium hydroxide, and then distillated. The residue was adjusted to $\mathrm{pH} 2-3$, extracted with ethyl acetate $(72.00 \mathrm{~kg} \times 3)$, washed with water and brine, and then dried. The crude product was crystallized from a binary solvent of $n$-BuOAc and heptane (4.4:0.85). The hot solution was cooled to $\sim 40^{\circ} \mathrm{C}$ naturally with stirring at first, followed by a second cooling to $\sim 20^{\circ} \mathrm{C}$ with the subsequent precipitation. The solid product was routinely centrifuged, washed and dried to get an off-white solid $(3.14 \mathrm{~kg}$, yield: 75\%, HPLC purity: 99.6\%). ${ }^{1} \mathrm{H}$ NMR (600 MHz, $\left.\mathrm{CD}_{3} \mathrm{OD}\right) \delta$ $3.68(\mathrm{~s}, 1 \mathrm{H}), 3.37-3.31(\mathrm{~m}, 1 \mathrm{H}), 2.38-2.33(\mathrm{~m}, 1 \mathrm{H}), 2.25-2.19$ (m, 1H), 2.03-2.01 (m, 1H), 1.97-1.74 (m, 7H), 1.63-1.61(m, $1 \mathrm{H}), 1.58-1.46(\mathrm{~m}, 6 \mathrm{H}), 1.44-1.30(\mathrm{~m}, 7 \mathrm{H}), 1.24-1.10(\mathrm{~m}, 3 \mathrm{H})$, $1.05-1.10(\mathrm{~m}, 1 \mathrm{H}), 0.99(\mathrm{~d}, J=6.6 \mathrm{~Hz}, 3 \mathrm{H}), 0.94(\mathrm{~s}, 3 \mathrm{H}), 0.93(\mathrm{t}$, $J=7.2 \mathrm{~Hz}, 3 \mathrm{H}), 0.72(\mathrm{~s}, 3 \mathrm{H}) .{ }^{13} \mathrm{C}$ NMR $\left(100 \mathrm{MHz}\right.$, DMSO- $\left.d_{6}\right) \delta$ 174.96, 70.61, 68.41, 55.55, 50.08, 45.33, 42.02, 41.28, 39.94, $35.53,35.19,34.94,33.54,32.63,30.83,30.76,30.43,27.83$, 23.08, 22.16, 20.41, 18.17, 11.69. HRMS $\mathrm{m} / \mathrm{z}$ calcd. for $\mathrm{C}_{26} \mathrm{H}_{44} \mathrm{NaO}_{4}[\mathrm{M}+\mathrm{Na}]$ 443.3132, found 443.3137.

Conflict of Interest

We declared no conflict of interest.

Acknowledgment

We thank Bingling Qiu (Xiamen Halosyntech Co., Ltd.) for his help in offering the key starting material 8-E.

\section{References}

1 Makishima M, Okamoto AY, Repa JJ, et al. Identification of a nuclear receptor for bile acids. Science 1999;284(5418):1362-1365

2 Wang H, Chen J, Hollister K, Sowers LC, Forman BM. Endogenous bile acids are ligands for the nuclear receptor FXR/BAR. Mol Cell 1999;3(05):543-553

3 FDA News Release. FDA approves Ocaliva for rare, chronic liver disease. Accessed April, 2021 at: https://www.fda.gov/news-events/ press-announcements/fda-approves-ocaliva-rare-chronic-liver-disease

4 Our Focus - Intercept Pharmaceuticals. Advanced fibrosis due to NASH puts patients at high risk of progressing to serious outcomes. Accessed April, 2021 at: https://www.interceptpharma.com/our-focus/nash/

5 Pellicciari R, Fiorucci S, Camaioni E, et al. $6 \alpha$-ethyl-chenodeoxycholic acid (6-ECDCA), a potent and selective FXR agonist endowed with anticholestatic activity. J Med Chem 2002;45(17):3569-3572

6 Pellicciari R. Steroids as agonists for FXR. WO Patent 2002/072598 September, 2002

7 Pellicciari R, Costantino G, Camaioni E, et al. Bile acid derivatives as ligands of the farnesoid $\mathrm{X}$ receptor. Synthesis, evaluation, and structure-activity relationship of a series of body and side chain modified analogues of chenodeoxycholic acid. J Med Chem 2004; 47(18):4559-4569
8 Shott LD, Borkovec AB, Knapp WA Jr. Toxicology of hexamethylphosphoric triamide in rats and rabbits. Toxicol Appl Pharmacol 1971;18(03):499-506

9 Steere NV. CXXX. Background information on hexamethylphosphoric triamide. J Chem Educ 1976;53(01):A12

10 National Toxicology Program. Toxicology and carcinogenesis studies of bromoethane (ethyl bromide) (CAS No. 74-96-4) in F344/N rats and B6C3F1 mice (inhalation studies). Natl Toxicol Program Tech Rep Ser 1989;363:1-186

11 Yu D, Mattern DL, Forman BM. An improved synthesis of $6 \alpha-$ ethylchenodeoxycholic acid (6ECDCA), a potent and selective agonist for the Farnesoid X Receptor (FXR). Steroids 2012;77 (13):1335-1338

12 He XL, Wang LT, Gu XZ, Xiao JX, Qiu WW. A facile synthesis of ursodeoxycholic acid and obeticholic acid from cholic acid. Steroids 2018;140:173-178

13 Ignacio HS, Yolanda FS, Carlos CL, Alfonso PE, José Angel TH. Process and intermediates for the synthesis of obeticholic acid and derivatives thereof. EP patent 3431486 A1. January, 2019

14 Ferrari M, Pellicciari R. Process for preparing $3 \alpha(\beta)-7 \alpha(\beta)$-dihydroxy- $6 \alpha(\beta)$-alkyl-5 $\beta$-cholanic acid. WO patent 2006122977 A2. November, 2006

15 André S, Heidi W, Emilie J, et al. Preparation, uses and solid forms of obeticholic acid. WO patent 2013192097 A1. December, 2013

16 Sepe V, Ummarino R, D’Auria MV, et al. Conicasterol E, a small heterodimer partner sparing farnesoid $\mathrm{X}$ receptor modulator endowed with a pregnane $X$ receptor agonistic activity, from the marine sponge Theonella swinhoei. J Med Chem 2012;55(01):84-93

17 Zhang J, Yu JH, Ma SM, Xu XN, Xiao P. A method for preparing obeticholic acid and related compound. CN patent 106589039 A. April, 2017

18 Zhang FY, Chen QY, Liu P. Method for preparing obetichloic acid. WO patent 2016045480 A1. March, 2016

19 Zhang SJ, Wang S, Liu L, Tian WW. Method for manufacturing obeticholic acid and intermediate thereof. WO patent 2018010651 A1. January, 2018

20 Mahender RS, Sanjiv T, Nilav P, Sudhir S, Sudharshan R, Dahval S. An improved process for preparation of obeticholic acid. WO patent 2018220513 A1, December, 2018

21 Pellicciari R, Pruzanski M, Gioiello A. The discovery of obeticholic acid $\left(\right.$ Ocaliva $\left.^{\mathrm{TM}}\right)$ : first-in-class FXR agonist. In: Fischer J, Klein C, Childers WE. Successful Drug Discovery. 3rd ed. Weinheim: Wiley-VCH; 2018:197-244

22 Alsina J, Barany G, Albericio F, Kates SA. Pyrrolidide formation as a side reaction during activation of carboxylic acids by phosphonium salt coupling reagents. Lett Pept Sci 1999;6:243-245

23 Coste J, Le-Nguyen D, Castro B. PyBOP ${ }^{\circledR}$ : a new peptide coupling reagent devoid of toxic by-product. Tetrahedron Lett 1990;31:205-208

24 Feng WD, Zhuo SM, Zhang FL. Process research and impurity control strategy for obeticholic acid, a farnesoid $\mathrm{X}$ receptor agonist. Org Process Res Dev 2019;23:1979-1989

25 ICH. ICH Harmonised Tripartite Guideline: Impurities in New Drug Substances. Q3A(R2) 2006. June 18, 2021. Accessed at: https://database.ich.org/sites/default/files/Q3A\%28R2\%29\% 20Guideline.pdf

$26 \mathrm{Lv}$ B, Li CW, Guo C. Method for preparing chenodeoxycholic acid derivative. CN patent 111718388 A. September, 2020 